Haines Lyon, Charlotte ORCID:

https://orcid.org/0000-0001-8341-744X (2018) Democratic parent engagement: relational and dissensual. Power and Education, 10 (2). pp. 195-208.

Downloaded from: http://ray.yorksj.ac.uk/id/eprint/2236/

The version presented here may differ from the published version or version of record. If you intend to cite from the work you are advised to consult the publisher's version: https://doi.org/10.1177/1757743818756913

Research at York St John (RaY) is an institutional repository. It supports the principles of open access by making the research outputs of the University available in digital form. Copyright of the items stored in RaY reside with the authors and/or other copyright owners. Users may access full text items free of charge, and may download a copy for private study or non-commercial research. For further reuse terms, see licence terms governing individual outputs. Institutional Repository Policy Statement

\title{
RaY
}

Research at the University of York St John

For more information please contact RaY at ray@yorksj.ac.uk 


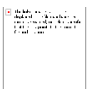

\section{Democratic parent engagement: relational and dissensual.}

\begin{tabular}{|c|c|}
\hline Journal: & Power and Education \\
\hline Manuscript ID & PAE-17-0011 \\
\hline Manuscript Type: & Democracy and Education Special Issue \\
\hline Keywords: & Democracy, Parent engagement, Parent voice, Dissensus, Ranciere \\
\hline Abstract: & $\begin{array}{l}\text { In opposition to the discourse of silent compliance and the neoliberal } \\
\text { colonisation of voice, this article shares research with parents in an English } \\
\text { primary school. Drawing on the work of Jacques Rancière and John } \\
\text { Macmurray, I argue that there is a need for a more relational but } \\
\text { dissensual approach to parent engagement and voice, instead of parents } \\
\text { being positioned by schools as support acts. Parent engagement, } \\
\text { increasingly commodified over recent years within English school policy, } \\
\text { has been relegated to responding to questionnaires, dutiful attendance of } \\
\text { parents' evenings, ensuring homework completion and choosing the correct } \\
\text { school. } \\
\text { Meanwhile the social mobility agenda demands that parents inculcate } \\
\text { aspirations in their children unquestioningly. Policies and pronouncements } \\
\text { seek to 'close the gap' in attainment between the poorest children and } \\
\text { their peers in England, Australia, the United States and other neoliberalised } \\
\text { countries. Hence a context is created in which parent engagement is now } \\
\text { an exercise in creating 'good' pupils and successful economic beings, } \\
\text { This article considers how parents have been rendered objects rather than } \\
\text { agentic subjects within neoliberal education systems and have lost their } \\
\text { democratic voice. It concludes that there needs to be a reanimation of } \\
\text { Dewey's (2013) vision of 'education politics' (Moutsios, 2010: 124). }\end{array}$ \\
\hline
\end{tabular}




\section{Introduction}

Increasingly, many aspects of western societies, notably education and health have been neoliberalised (Olssen et al., 2004; Rizvi and Lingard, 2010; Western et al., 2007). Although globally there are varying levels of privatisation, in anglophone countries such as England, Australia and the United States, both sectors have come under increasing levels of commodification. Competition between providers is claimed as essential to efficiency and good performance. Choice of provider is promoted as a responsibility to be exercised by consumers based on accountability data (Hursh, 2007). Under neoliberal education policies, choice of school has become the definition of democratic voice.

Furthermore, as the neoliberal project progresses, inequality has widened in the United States, Australia and the United Kingdom (Hills, 2015; Rizvi and Lingard, 2010). All three countries are in the top ten industrialised countries for unequal incomes. The United States is second (to Chile), the United Kingdom fifth and Australia ninth (Hills, 2015: 27). This gap in income further translates into a gap in achievement in schools between the most disadvantaged children and their peers, this is especially so in the UK (OECD, 2010). Whereas in the United States and Australia, education inequality initiatives have been largely race focussed (Hursh, 2007; Ministerial Council for Education, Early Childhood), the UK initiatives have been very much class based (OFSTED, 2013). The narratives within the discourses and policies, however, are very similar. The policies designed to close the inequality, individualise and further instrumentalise parents by reifying specific models of parenting that supposedly ensure good results and accordingly acceptable economic beings. As Ramaekers and Suissa (2011) point out, this narrow view of parenting has become an individualistic exercise in transmission from parent to child. This instrumentalisation of parent engagement within neoliberal education systems, especially within England has commodified parents and thus 
removed their agency as human beings. Furthermore, there is an implied consensus as to the shape of parent engagement.

This article will draw on doctoral research that sought to counter the individualistic narrative of choice and instrumentalisation, instead embracing the agency of parents regarding the home- school relationship. Building on the work of Jacques Rancière and John Macmurray an argument will be made for a more democratic, relational but dissensual form of parent engagement. This entails a move away from an instrumentalist view of the home-school partnership towards a more Deweyian model of 'education politics,' in which parents, along with teachers and pupils, might be able to shape education policy rather than submit to it (Moutsios, 2010: 124).

\section{Context}

Neoliberalism connotes individualism, free markets, consumerism and minimal state intervention with competition as the final arbiter; any intervention that the state makes is for the protection and functioning of the markets rather than for the sake of the individual or community (Rizvi and Lingard, 2010). This is in direct opposition to the social democratic concept of people living in relationship with each other, negotiating power dynamics, social values and tensions (Rizvi and Lingard, 2010). In the anglophone states including the United States, Australia and England, education has become increasingly focussed on creating human capital (Connell, 2013; Olssen, 2010). The results of high stakes tests are of the utmost importance, with concepts of well-being, social skills, and political understanding being side-lined if not eviscerated.

Dewey (1922: 111) complained that too many saw education as a means to solving today's problems, rather than 'the proper end of education: the promotion of the best realization of humanity as humanity'. This still applies today, with education policy being dictated by the apparent needs of now, by the government and employers rather than necessarily wider 
social goods. As Fielding and Moss (2010:15) argue, schools are 'at risk of being a place of regulation and normalization, tasked with producing subjects fit for the purposes of the nation state and the capitalist economy'. Similarly, parents are now positioned as subjects fit for economic purpose rather than citizens 'empowered to influence the education that in turn shapes the political values, attitudes, and modes of behaviour of future citizens' (Gutmann, 1987: 14).

Thus

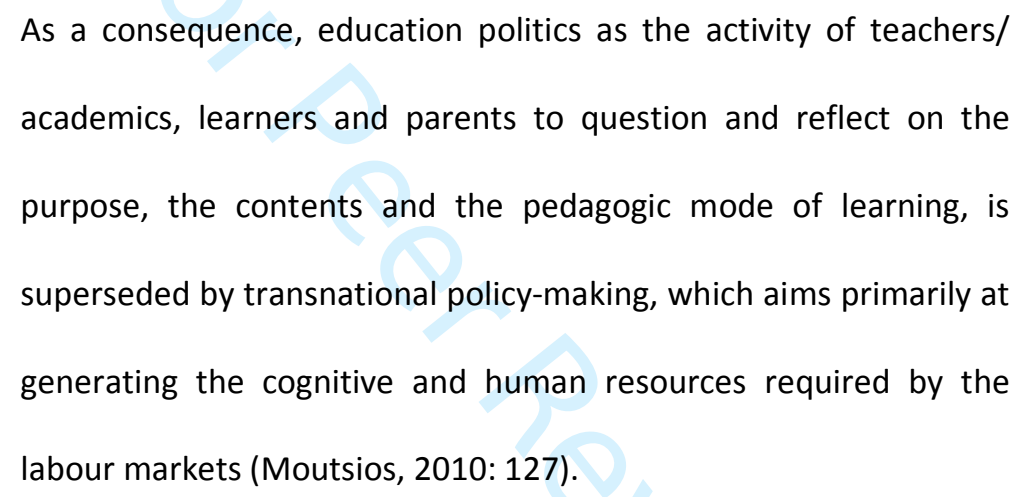

Choice

Whilst countries are competing in the global market place, and within the PISA rankings (OECD, 2015), individual schools have been forced to compete against each other within their own locality with the introduction of standardised tests and publication of their results. School performance in these tests is used as criteria for competition, as parents choose the 'best' school for their children. This data is readily accessible, either through government websites such as http://www.myschool.edu.au/ in Australia, a plethora of websites in the US including www.schooldigger.com, and School Performance Tables in the UK (Department for Education, 2014). 
Choice is key to the market logic. As competition enables more efficient production rates (whether of factories, or indeed schools), and the ability to choose between the best school and its failing neighbour is essential. In order to promote standards, the logic 'assumes that market arrangements will always produce better outcomes than government regulation' (Angus, 2015: 396); if a school roll starts to drop, then the school will improve in order to regain pupil numbers.

Choice of school thus comes at the expense of social cohesion as parents are expected to choose the best school rather than the community school (Weller, 2012). Reay (2008) argues that school choice, is now understood as the act of a responsible parent and, moreover, the wrong school choice is the act of an irresponsible parent. To choose the best school has become a moral act, and thus parents have been responsibilised (Reay, 2008: 645; Shamir, 2008). This is problematic, not least because the grounds for choice are spurious and, certainly in England, the choice is not actually there. For example, there may be no local school designated 'Good' or 'Outstanding', the parents may not be allocated their first choice of school, or the parents may not have the resources to choose or transport their child to the 'best' school (Adams, 2017; Vincent, 1996a). Thus, as Reay (2008:643) argues, 'the ability to take up [this] new parental [position] - as active chooser. . . - is differentially distributed according to social class'.

The logic of choice, has deposed the more social democratic concept of participation in institutional life (Beattie, 1985); it equates the choice of joining (or withdrawing) from a school to participative power (Vincent, 1996b). As Ball (2003: 32-32) argues, this notion of choice within schooling has become very utilitarian with the concept of values being relegated as old fashioned or needless. Thus, parents have been placed not as citizens involved in a shared endeavour of bringing up new citizens, but as 'choosing subjects' (Angus, 2015: 396). Democratic voice has become colonised by the concept choice. 


\section{Consensus}

As Biesta (2016: 55). argues 'It is, of course, important to acknowledge that parental choice in itself can hardly be called democratic if it is not a part of wider democratic deliberation about the shape and form and ends of education in society' Neoliberal education systems, have removed the ability and space for such deliberation.

In England, some parents and parents' groups protested in 2016 against the implementation of a new form of testing for six and seven year olds (year 2 ) and ten and eleven year olds (year 6); a particularly technical grammar test provoked significant consternation. Nick Gibb, the schools minister, claimed that the tests were necessary because 'if you do not come from a home where your parents speak in a grammatically correct form and if you do not have a home surrounded by books where reading is the daily occurrence, they (those children) need that structural instruction,' (TES, 2016 ).

London Free school founder and columnist Toby Young opined (Young T, 2016):

moronic, selfish middle-class warriors [are] entrenching class divisions. . . it's kids from disadvantaged backgrounds who are penalised by this therapeutic approach. The children of the middle-class protestors will be fine if they spend all day finger-painting because they'll pick up the basics at home; it's their less affluent peers who will suffer.

Consequently, parental debate within the mainstream media about the rights and wrongs of these tests and the direction of the education system was shut down. Middle class parents were positioned as self-interested enemies of promise and disadvantaged parents too inept for their children to succeed at school. Democratic debate was shut down.

Brown (2015: 22) argues that neoliberalism has led to people (and I would argue schools) needing to behave in investible ways, rather than moral or democratic ways. Schools need to 
be seen as succeeding in the high-stakes testing and accountability measures. In the UK, they are also expected to demonstrate parental support and consensus by way of Parent View (a questionnaire completed by parents that the inspectors from OFSTED use as part of its judgment found at https://parentview.ofsted.gov.uk/). If a school does not adhere to the required standards (i.e. fails the high stakes testing requirements), it will be disciplined by way of privatisation and reform. In the United States 'failing schools' are forced to become Charter schools and in the UK they are forced to convert to Academies (Burns, 2015; Hursh, 2007). A similar policy has been advocated in Australia (Zyngier, 2015). There is no room for deviation. It is unsurprising then, that parents can feel pressurised to compliantly support the school and children to succeed in tests. Hursh (2007) suggests that the real purpose of these apparent accountability procedures is to speed up the route towards privatisation, rather than school improvement.

Even the democratic role of parent governors in England is debateable with pressure to agree with the head and general education policy. The role of governors is often to maintain a harmonious consensus; as Young (Young H, 2016) maintains, 'The conception of a singular common good and the constitution of education and governing as apolitical operate against the discussion of alternative conceptions of 'good' education to that of the national performative system'. The apparent need for consensus has become more a demand for silent compliance within a system, thus further removing democratic voice of parents.

\section{Removal of agency}

Australia, the United States and the United Kingdom have all recognised that there is a gap between the academic attainment of the poorest children and their contemporaries. They have each developed a range of policies intended to close this gap. The Australian 'gap' is portrayed as being between Aboriginal children and their white peers (Ministerial Council for Education, Early Chilhood Development and Youth Affairs) and the USA similarly has focussed 
on a race based gap (Hursh, 2007). England however has focussed on the gap between working class white children and their peers (OFSTED, 2013); the problematic conflation of working class and disadvantage notwithstanding (House of Commons Education Committee, 2014: 3; OFSTED, 2013; Perry and Francis, 2010).

The UK's 2010 Coalition government and the current Conservative government have touted parental engagement as the panacea for the achievement gap between the poorest children in England and their contemporaries. Michael Wilshaw (2013), the then Chief Inspector of Schools in England, stated that 'poverty of expectation is a greater problem than material poverty'; the raising of aspirations is commonly purported to be key to narrowing inequality (Baker et al., 2014; OFSTED, 2013; Sharples et al., 2011; Sodha and Margo, 2010; Vasagar, 2011). This assertion is heavily criticised by some researchers who argue that there is no evidence for a lack of aspiration but rather there is a problem with the lack of resources and often barriers to achieving such aspirations (Carter-Wall and Whitfield, 2012; Kintrea et al., 2011; Perry and Francis, 2010). The policies designed to 'close the gap' in Australia, the United States and England all individualise the problem of poverty through pathologising economically poorer parents, rather than questioning the vast structural inequities.

Many models of parenting and parental engagement, advocated within these policies, mirror those of middle class families. As Lareau (2011) describes, her ethnographic research with parents indicated middle class families tend to use 'concerted cultivation' to parent; ensuring the child experiences different activities including sports and arts to accumulate cultural capital in order in the hope of boosting economic prospects. The working-class parents that she worked with tended to view parenting as more 'natural growth' including free play and time with family. Problematically, Lareau found that schools tended to value the concerted cultivation more than the natural growth style of parenting. Thus, parent engagement 
becomes a mechanism for 'conversion' of problem parents to 'acceptable' ones (Lumby, 2007; Reay, 2008).

Invoking Dewey's (2013), concept of the 'wisest parent' Bates (2011: 314) asks how we 'ensure the "best and wisest" parent becomes the norm?'. His question not only implies that someone other than the parent is ensuring the norm, but that there is a singular consensus as to the make-up of this best parent. As Williams (2004: 26) argues, parenthood and parenting have been subjected to increasing 'public regulation' and scrutiny; there have been many diktats as to how to parent, especially aimed at the most financially disadvantaged parents. This has included the need for parents to gain good jobs with an increasing pay (Social Mobility and Child Poverty Commission, 2014), which was published at a time of frozen pay within the public services in the UK.

Furthermore, a wider angst has been created as to how difficult parenting is, with 'routes to such functioning defined by the latest research in psychology; parents are understood to be responsible for attaining a certain (preconceived) idea(I) of what "good", well-behaved children are' (Ramaekers and Suissa, 2011: 136). These evermore scientific answers have resulted in framing parents as simple followers of instructions which Ramaekers and Suissa (2011) argue results in removing moral agency, and voice. This is an extremely problematic; 'treating people as if they lack that capacity is to treat them as if they were not human' (Couldry, 2010: 1).

As Ramaekers and Suissa (2011) point out, this narrow view of parenting, has become about transmission from a parent to the child in an extraordinarily individualistic way. The neoliberal education system's model of parental engagement has removed the democratic agency of parents, and created a narrative in which a 'good parent' makes responsible choices instead of voicing opinion, silently supports the neoliberal consensus and has no moral capacity to parent. Parents have not only been instrumentalised in the production of 
economic beings, but have been individualised and removed from the task of 'democratic deliberation about the shape and form and ends of education in society' (Biesta, 2016: 55).

\section{Doctoral Research}

Pring (2012: 749) argues that neoliberal education has objectified learners who are valued for their ability to affect 'the place of the school in the league table, the successful attainment of targets, the supply of skilled workers.'. I argue that parents have been objectified in the same way, valued for how they affect the overall results of a school; behaving in in investible ways (Brown 2015). Echoing Macmurray, Pring (2012:747) advocates 'put[ting] persons back in to education'. It is with this desire to put parents as persons back into education that I carried out my doctoral research. The aim was to provide a space in which parents would be able to question policy, practice and the narratives of parent engagement within the school. Thus, trying to recreate a Deweyian dialogue in which people with different views could 'have equable opportunity to receive and to take from others.'

(Dewey, 1922: 97).

As I have argued, parental agency is often removed or relegated null and void by the government and or education professionals, therefore Critical Participative Action Research Methodology (Kemmis, 2008; Kemmis et al., 2014) was used to ensure participants - parents in an English primary school - were able to shape the research, question their own practices and those of the school. To date, the project has involved ten meetings with participants over two years.

Five of these meetings took the form of Community Philosophy. Community Philosophy is one of many forms of community of inquiry and philosophical communities, including Skeptics and Philosophy Clubs (Evans 2012). It is an adaptation of Philosophy for Children (P4C); a scheme developed by Matthew Lipman and provided in schools in the UK, through SAPERE (2013; 2015a). More recently SAPERE (2015b) have 'extended the ' $C$ ' to include 
colleges and communities' rather than denoting just children. Lipman built on the work of John Dewey arguing that all inquiry must be social (Dewey, 1922; Evans, 2012; Lipman, 2003). Lipman (2003: 94) promoted 'non adversarial deliberations and shared cognitions'; dialogue within a group building an argument rather than a partisan debate. The non-adversarial nature of Community Philosophy was attractive to participants and the headteacher, who feared the project might become a 'moaning shop'. Participants liked the idea of exploring issues and developing arguments and in turn actions that might arise from the discussions. For example, in one meeting, the importance of being able to speak informally with teachers was explored in depth and the participants agreed to meet with the headteacher to explore how this might work in practice.

These meetings were held in an adjacent community centre and with no staff from the school present. Whilst there was initially some interest from parents, numbers soon dwindled and three regular participants attended meetings, with a handful of other parents attending different meetings throughout the project. Participants said the difficulty in maintaining numbers, was due to the expectation to do something in the meetings. It was argued that supporting each other, and sharing stories as part of the meeting was important, thus, after continual reflection and negotiation, formal Community Philosophy was gradually dropped, although the group still maintained an attitude of enquiry but with a stronger emphasis on support for parents. After five meetings and falling numbers, the remaining participants asked to meet with the headteacher to explore some of the issues raised in our discussions.

\section{Relationships}

A common theme throughout the meetings was for easier and more informal communication and relationships with the school, rather than more meetings or formal initiatives such as Community Philosophy. One of the most memorable moments of the project was the 
excitement of a participant reporting that the headteacher had come out of his office to say hello to some of the parents; this had more impact than a variety of official initiatives to work with parents. The meetings with the headteacher have since explored different options as to how this might work, but health and safety issues are often cited as a barrier to simple parent-school relationships being built. In an attempt to counter the barriers to communication, the headteacher has instigated a new project in which surveys will be used regularly via email and social media.

Whilst home-school partnerships are claimed by the school, and parents' voices are sought via surveys, it is difficult for parents to access staff. It is a one-sided power relationship with staff being able to open or shut the door, to agree and arrange meetings. As Lareau (1989: 35) identifies it is more convenient for teachers to maintain a 'professional -client relationship' rather than a partnership in which 'power and control is equally distributed.' Parents are expected to choose the school, respond to questionnaires and feedback when asked. They are not expected to instigate relationships or question what is occurring within the wider running of the school. For example, whilst there are new events to teach parents how to help their child with maths, there is no space to question the new maths initiative.

In opposition to voice being relegated to choice and survey response, Couldry argues that narrative is essential (2010); not only does one need to tell their story, 'to give account' but that account needs to be heard. If it is possible for interactions between staff and parents in a more open and equal way, it might be possible as Dewey (1922:101) argues, for a breakdown of 'those barriers of class, race, and national territory which keep men [and women] from perceiving the full import of their activity'. If staff and parents could understand their impact on others, especially regarding the education of the children, it might make for the partnership espoused by schools. 
It is essential to consider how parents and schools relate to each other, if we are to move beyond the instrumentalisation of parents in education. Macmurray (2012: 667ff) argued that education was not simply about creating functional citizens but to enable children to 'learn to be human'. For this to happen, children need to relate to others within a complex community; a school. I would argue that children need to see adults relating to each other too. As the headteacher of the school I worked with stated, 'for a child to see a parent talking to a teacher- it's nice but quite rare.'

Informal opportunities to relate, enable the contemplation of each other that Macmurray advocates (1950; 1961), which leads to the taking in to account of our impact upon each other that Dewey (1922) promoted. Telling our stories and hearing others stories, beyond choosing boxes in surveys allows for 'the relation of fellowship' rather than the 'relation of master and servant' (Macmurray, 1950: 29). It is through contemplating each other and taking each other into account, Macmurray (1950) argues that we can make effective decisions as to how to live, take action, and reflect on the consequences of that action. This, not choosing at the ballot box he argued, is democratic living.

\section{Problematic consensus and dissensual agency}

As the research project continued, participants became increasingly frustrated with the apparent need to be harmonious and the non-adversarial nature of Community Philosophy. Early on a participant left the project saying that they did not like critique of the school as it was disloyal. Other participants felt that critique was necessary to improve a situation. At a later meeting, a participant expressed anger and frustration at how they had been treated by the school but also other parents. The original design of meetings was aimed to prevent such an outburst, but we had dropped the precise format by this point. The meeting was very uncomfortable for many of us, however, it led to personal reflection on behalf of several participants and changes in behaviour and thought. After this meeting, participants 
expressed the need for more grit in the oyster, and more adversarial debate rather than trying to work towards some form of consensus by the end of each meeting.

The topic of supporting children's education was discussed at one meeting. Several participants were quite vociferous that parents must read with their children every night. One felt sad for children whose parents didn't read with them. One felt angry that some parents seemingly neglected their children through such lack of support. Then another participant retorted that she felt her child was so exhausted after school, it was her responsibility as a good mother to not read with their child but to get them to sleep. The group then started to explore the concept of withholding support as being supportive. This intervention by one mother had challenged others as to their assumptions about what makes for the 'best and wisest' parent. This led to further discussions about how different parents might have different needs, priorities and values for a wide range of reasons. There was no consensus as to the best form of support.

Macmurray (1961) argues for the need of a habit of social cooperation that is developed from the experienced cooperation within families and school. In Conditions of Freedom, Macmurray (1950) extends this argument to a plea for a 'universal fellowship' united in values and friendship. Glass (2008) points out that Dewey's thinking, and I would argue Macmurray's thinking assumes that everyone's values are similar. However, as the homework discussion illustrates in a micro sense, there are myriad values and ways of parenting. The ongoing Brexit debate in the UK, provides a glimpse as to how divergent values and political stances can be in the macro. Consensus is not possible, and not necessarily desirable.

In the light of participants arguing for more opportunities to informally relate to teachers and the failure to sustain regular Community Philosophy meetings, it could be assumed that Community Philosophy has no role in the democratic life of a school. However, I would argue 
that while the format was not necessarily appropriate or successful, the opportunity for philosophical thinking about the wider issues of education beyond an individual child's progress, is important for the school community. But such an opportunity does not need to be formalised as with Community Philosophy. Some of the participants are planning to meet together in a café before they next meet with the headteacher. They said this will give them space to question and think about what they want to say rather than turn up to a meeting and feel they should agree with everything that is being said. As one participant stated, 'I feel a bit ambushed when I go in, I feel I have to be nice and get on side. I think I am the only one who feels this but it turns out I am not.' The participants are now creating their own space in which to question the order of things. Other parents are doing that on their own and making their way to the headteacher to question things. The headteacher has reported other parents doing similar and that he is now welcoming parents into the school who take issue with policy and practice, whereas previously they had been kept at a distance.

Rancière (1999) argues that a 'common sense' pervades, in which there is a sense of place and role. Within education, it might be assumed that the parents place is outside of school; at home. The role of a parent is to choose wisely and support the school and child appropriately. Rancière (2010: 46$)$ argues that the simplest way to exclude people from the demos is to 'assert that they belonged to the 'domestic space' rather than public space in which acceptable public voices are permitted to govern. This place and role, according to Rancière (1999: 29) is allotted by the police; he explains the 'police' as 'an order of bodies that defines the allocation of ways of doing, ways of being, and ways of saying. . '

Returning to the earlier discussion of the English parent's protest against primary testing, one may consider the framing of parents by Gibb (TES, 2016) and Young (Young T 2016) as policing. This episode, along with other pronouncements about parental aspirations, contributed to the order of apparent 'common sense' regarding instrumentalist, obedient 
parenting. Furthermore, Rancière (2010) argued that certain people are deemed capable of membership of the police order and others are not. Those whom are excluded have their voices rendered as simply noise. The treatment of the parents' protest' by Gibb and Young could be argued to be rendering parent's voices as noise, incapable of making coherent common sense arguments.

Returning to my doctoral research, we can see how a 'common sense' had developed regarding what a supportive parent looked like. But more importantly a participant who did not share the 'common sense' spoke out and ruptured the consensus. Rancière $(1999 ; 2010)$ argues that this speaking out and rupturing the common sense is the political act. It is this speaking out against the common sense, and the assumption that 'I have the capability of speaking as you do' that establishes the assumption of equality and assumption of humanity (Bingham et al., 2010). This act of rupture or dissensus provides a counter to Ramaekers and Suissa's (2011) concern that positioning parents as followers of instructions removes their moral agency. It is essential that parents question the' common sense' and disrupt the status quo if they are to maintain their agency.

Our original desire to use a non-adversarial form of discussion and aim for deliberative consensus was partly to avoid conflict. From the headteacher's point of view, it was possibly to maintain a general supportive consensus for the school. However, Rosanvallon (2008: 313) maintains that conflict is essential to democratic life:

Conflict is inevitable in such a project, because debate brings to light the actual transfer of resources that takes place among individuals, groups, and regions, reveals hidden legacies of the past, and discloses implicit regulations. Such a debate has nothing in common with the calm, almost technical kind of discussion envisioned by certain theorists of deliberative democracy. However difficult the exercise, it is nevertheless essential as a 
way of gaining practical experience of the general will. (Original emphasis).

Rosanvallon (2008) further argues that democracy needs to be kept in check; it is necessary for people to disagree, for people to question the order of things; 'a counter policy'. Within the school it is essential that we do not try to maintain a harmonious consensus, requiring passive parents. Ranciere (1999: 77) defines dissensus, 'a division inserted in 'common sense': a dispute over what is given and about the frame within which we see something as given'. Dissensus is vital if we are to move beyond technical democracy but to continually debate and shape the 'form and ends of education in society' (Biesta, 2016: 55).

However, Rancière's concept of dissensus whilst helpful, might imply a solitary initiative rather than a social action, which in the light of the participants' need for relation and sharing stories might be problematic. However, reading his argument alongside Macmurray is helpful. Macmurray (1961: 61) argues that the 'unit of the personal is not the ' $\mathrm{l}$ ' but the 'You and I' and that it when we interact with each other we come into full being and realise our subjectivity. Whilst Rancière's subjectivity is gained when the political act is made, this act follows from the initial premise, that 'I am equal to you' and will act as if this is true (Rancière, 1991;1999;2014). Thus, Rancière could also be said to be assuming that the unit of the personal is 'You and I'. Whilst Macmurray reminds of the need to pay attention to our relationship with others, Rancière ensures that good relationships do not come at the cost of democracy and voice, but rather welcome dissensus.

\section{Conclusion}

Throughout this article I have referred to attempts to define the 'best and wisest parent'. Dewey (2013: 19) declared that 'What the best and wisest parent wants for his own child, that must the community want for all of its children. Any other ideal for our schools is narrow and unlovely; acted upon, it destroys our democracy'. However as I have argued sometimes 
the concept of 'best and wisest parent' is problematic, with it often being assumed as 'common sense'. This necessitates, the need for relationships between parents and between staff and parents, which allow for narrative and agency of all parties. As Biesta (2016: 71) argues, the accountability culture, has made relationships between schools and parents distrustful from both sides. There need to be 'mutual, reciprocal and democratic relationships. . .based upon the shared concern for the common educational good.' To have a democratic form of education necessitates different views of this common good, and different understandings of the 'best and wisest parent'. It is vital that this does not become a 'common sense', rendering some people voiceless or lacking agency.

In conclusion, I have demonstrated that neoliberal education systems have colonised democratic voice, by promoting choice, supportive consensus and detailed parenting structures which remove agency. This colonisation has instrumentalised and individualised parents in education, thus domesticating parent engagement rather than understanding and shaping of education as a joint enterprise between parents, educators and society.

If children are to learn from Dewey's (1922) broad range of experiences, then it is necessary to recognise and embrace the heterogenous array of family lives and values. The very involvement of parents in questioning and debating the wider aspects of education necessitates pluralism and dissensus. Negotiating the tensions involved in this endeavour requires contemplating one another in a Macmurrayian sense and providing space and time for relationships. Nevertheless, this must not demand passive harmony and 'common sense'. Indeed, there may be many contrary best and wise parents that trouble the common sense. This should be welcomed for the democratic life of not only schools but of society. Thus, a school that is prepared to relate to parents and prepared for dissensus is one providing a counter to the neoliberal discourse of silent compliance. 


\section{References}

Adams R. (2017) Poorer children half as likely to get into best schools, research shows. The Guardian. Available at https://www.theguardian.com/education/2017/apr/17/poorer-children-half-aslikely-to-get-into-best-schools-research-shows (accessed 17/04/2017).

Angus L. (2015) School choice: neoliberal education policy and imagined futures. British Journal of Sociology of Education 36(3): 395-413.

Baker W, Sammons P, Siraj-Blatchford I, et al. (2014) Aspirations, education and inequality in England: insights from the effective provision of pre-school, primary and secondary education project. Oxford Review of Education 40(5): 525-542.

Ball S J. (2003) Introduction. In: Vincent C (ed) Social justice, education and identity, London: Routledge.

Bates T. (2011) Expectation, aspiration, motivation: parents do matter. Professional Development in Education 37(3): 313-318.

Beattie N. (1985) Professional parents : parent participation in four Western European countries, London: Falmer Press.

Biesta G. (2016) Good education in an age of measurement : ethics, politics, democracy, London: Routledge, Taylor \& Francis Group.

Bingham CW, Biesta G and Rancière J. (2010) Jacques Rancière : education, truth, emancipation, London: Continuum.

Burns J. (2015) All failing schools to be academies under new bill. Available at: http://www.bbc.co.uk/news/education-32978355 (accessed 21/04/2017) 
Carter-Wall C and Whitfield G. (2012) The role of aspirations, attitudes and behaviours in closing the educational attainment gap, York: Joseph Rowntree Foundation. Available at: https://www.jrf.org.uk/report/role-aspirations-attitudes-andbehaviour-closing-educational-attainment-gap (accessed 21/04/2017)

Connell R. (2013) The neoliberal cascade and education: an essay on the market agenda and its consequences. Critical Studies in Education 54(2): 99-112.

Couldry N. (2010) Why voice matters: culture and politics after neoliberalism, London: SAGE. Department for Education. (2014) School performance tables. Available at: http://www.education.gov.uk/schools/performance/index.html (accessed 20/02/2017)

Dewey J. (1922) Democracy and education: An introduction to the philosophy of education, New York: The Macmillan Company.

Dewey J. (2013) The school and society, Miami: Hardpress Publishing.09

Evans J. (2012) Connected communities - philosophical communities. London: Queen Mary, Univesity of London, Arts and Research Council.

Fielding M and Moss P. (2010) Radical education and the common school : a democratic alternative, London: Routledge.

Glass R. (2008) Education and the ethics of democratic citizenship. In: Katz MS, Verducci S and Biesta G (eds) Education, democracy, and the moral life, Dordrecht: Springer.

Gutmann A. (1987) Democratic Education, Princeton: Princeton University Press.

Hills J. (2015) Good times, bad times : the welfare myth of them and us, Bristol: Policy Press. House of Commons Education Committee. (2014) Underachievement in education by white working class children, London: House of Commons.

Hursh D. (2007) Assessing No Child Left Behind and the rise of neoliberal education policies. American Educational Research Journal 44(3): 493-518. 
Kintrea K, St Clair R and Houston M. (2011) The influence of parents, places and poverty on educational attitudes and aspirations, York: Joseph Rowntree Foundation.

Lareau A. (1989) Home advantage: social class and parental intervention in elementary education, Philadephila: The Falmer Press

Lareau A. (2011) Unequal childhoods class, race, and family life, Berkley: University of California Press.

Lipman M. (2003) Thinking in education. 2nd ed. New York: Cambridge University Press

Lumby J. (2007) Parent voice: knowledge, values and viewpoint. Improving Schools 10(3): $220-232$.

Macmurray J. (1950) Conditions of freedom, London: Faber and Faber.

Macmurray J. (1961) Persons in relation, London: Faber and Faber.

Macmurray J. (2012) Learning to be human. Oxford Review of Education 38(6): 661-674.

Martin D. (2011) Matthew Lipman, philosopher and educator, dies at 87. New York Times, 14/01/2011. Available at: http://www.nytimes.com/2011/01/15/education/15lipman.html laccessed 21/04/2017).

Ministerial Council for Education, Early Childhood Development and Youth Affairs. Aboriginal and Torres Strait Islander education action plan 2010-2014. South Victoria. Available from:

http://www.scseec.edu.au/site/DefaultSite/filesystem/documents/ATSI\%20documen ts/ATSIEAP web version final.pdf (accessed 21/04/17)

Moutsios S. (2010) Power, politics and transnational policy-making in education. Globalisation, Societies and Education 8(1): 121-141.

OECD. (2010) PISA 2009 results: overcoming social background: equity in learning opportunities and outcomes (Volume II), Paris: OECD Publishing. Available at: 


\section{http://www.oecd-ilibrary.org/education/pisa-2009-results-overcoming-social-}

background 9789264091504-en (accessed 21/04/17)

OECD. (2015) About PISA. Available at: http://www.oecd.org/pisa/aboutpisa/ .(accessed 21/04/17)

OFSTED. (2013) Unseen children: access and achievement 20 years on. London: OFSTED.

Olssen M. (2010) Liberalism, neoliberalism, social democracy : thin communitarian perspectives on political philosophy and education, New York: Routledge.

Olssen M, Codd JA and O'Neill A-M. (2004) Education policy : globalization, citizenship and democracy, London: Sage Publications.

Perry E and Francis B. (2010) The social class gap for educational achievement: a review of the literature, London: RSA Projects. Available at:

https://www.thersa.org/discover/publications-and-articles/reports/the-social-classgap-for-educational-achievement-a-review-of-the-literature (accessed 21/04/2017)

Pring R. (2012) Putting persons back into education. Oxford Review of Education 38(6): 747760.

Ramaekers S and Suissa J. (2011) The claims of parenting: reasons, responsibility and society, London: Springer.

Rancière J. (1999) Disagreement : politics and philosophy, Minneapolis: University of Minnesota Press.

Rancière J. (2010) Dissensus on politics and aesthetics, London: Continuum.

Rancière J. (2014) Hatred of democracy, London: Verso.

Rancière J. (1991) The ignorant schoolmaster: five lessons in intellectual emancipation, Stanford: Stanford University Press.

Reay D. (2008) Tony Blair, the promotion of the "active" educational citizen, and middle-class hegemony. Oxford Review of Education 34(6): 639-650.

Rizvi F and Lingard B. (2010) Globalizing education policy, London: Routledge. 
Rosanvallon P. (2008) Counter-democracy: politics in an age of distrust, Cambridge: Cambridge University Press.

SAPERE. (2013) Philosophy for Children. Available at: http://www.sapere.org.uk/Default.aspx?tabid=162 (accessed 21/04/17)

SAPERE. (2015a) Community Philosophy. Available at: http://www.sapere.org.uk/Default.aspx?tabid=102 (accessed 21/04/17)

SAPERE. (2015b) What is P4C. Available at: http://sapere.org.uk/Default.aspx?tabid=162

Shamir R. (2008) The age of responsibilization: on market-embedded morality. Economy and Society 37(1): 1-19.

Sharples J, Slavin R, Chambers B, et al. (2011) Effective classroom strategies for closing the gap in educational achievement for children and young people living in poverty, including working class boys. London: Centre for Excellence and Outcomes in Children and Young People's Services. Available at: http://archive.c4eo.org.uk/pdfs/3/Schools\%20and\%20Communities\%20RR\%20P4.pd $\underline{f}$ (accessed 21/04/2017)

Social Mobility and Child Poverty Commission. (2014) How the Key Players Outside Central Government Can Tackle Child Poverty and Promote Social Mobility. London: SMCPC. Available at https://www.gov.uk/government/uploads/system/uploads/attachment data/file/39 1765/Advice to Ministers - other actors.pdf (accessed 21/04/2017)

Sodha S and Margo J. (2010) Excurricula. London: Demos. Available at: https://www.demos.co.uk/project/ex-curricula/ (accessed 21/04/2017)

TES. (2016) Nick Gibb admits he had already seen the grammar question he got wrong live on air. The TES Available at: https://www.tes.com/news/school-news/breakingnews/nick-gibb-admits-he-had-already-seen-grammar-question-he-got-wrong (accessed 21/04/2017) 
Vasagar J. (2011) Education chief identifies white working-class pupils as big challenge. The Guardian. London. Available at: https://www.theguardian.com/education/2011/sep/23/education-chief-whiteworking-class-challenge (accessed 21/04/2017)

Vincent C. (1996a) Parent empowerment? Collective action and inaction in education. Oxford Review of Education, 22(4): 465-482.

Vincent C. (1996b) Parents and teachers: power and participation, London: Falmer.

Weller S. (2012) School choice versus social cohesion: examining the ways education policies shape children's geographies in the UK In: KraftI P, Horton JD and Tucker FJ (eds) Critical geographies of childhood and youth : policy and practice, Bristol: Policy Press.

Western M, Baxter J, Pakulski J, et al. (2007) Neoliberalism, Inequality and Politics: The Changing Face of Australia. Australian Journal of Social Issues (Australian Council of Social Service). 42(3): 401-419.

Williams F, Professor. (2004) Rethinking families, London: Calouste Gulbenkian Foundation.

Wilshaw M. (2013) Unseen cChildren - HMCl speech. Available at: http://webarchive.nationalarchives.gov.uk/20131216154121/https://www.ofsted.go v.uk/resources/unseen-children-hmci-speech (accessed 21/04/2017)

Young, H. (2016) Busy yet passive: (non-)decision-making in school governing bodies. British Journal of Sociology of Education, Advance online publication. Available at http://wwwtandfonline-com.yorksj.idm.oclc.org/doi/full/10.1080/01425692.2016.1158641 (accessed 6/04/2017)

Young T. (2016) Status Anxiety: If the Sats-strike parents get their way only the poorer kids will suffer. Available at: http://www.spectator.co.uk/2016/05/if-the-sats-strike-parents-gettheir-way-only-the-poorer-kids-will-suffer/ (accessed 21/04/2017)

Zyngier D. (2015) Charter schools: an old flawed idea and wrong for Australia. Available at: http://www.aare.edu.au/blog/?p=1220 (accessed 21/04/2017) 
